\title{
NATURAL SUCCESSION OF SECONDARY-LOWLAND DIPTEROCARP FOREST AFTER SELECTIVE LOGGING IN LONG PAHANGAI, WEST KUTAI, EAST KALIMANTAN
}

\author{
Retno Peni Sancayaningsih* and Misbakhul Bait \\ Laboratory of Ecology and Conservation, Faculty of Biology, Gadjah Mada University, Yogyakarta, Indonesia \\ *retpeni@ugm.ac.id
}

\begin{abstract}
Selective logging in West Kutai may raise vegetation and environmental destruction in lowland Dipterocarp forest, and this will naturally run into succession. The purposes of this research were to study secondary succession in lowland Dipterocarp forest after 8 months and 6 years of Selective Logging in Long Pahangai, West Kutai regency, East Kalimantan and to study the relationships between plant abundance and soil nutrients and other environmental factors. The research had been done from May to November 2012. Nine study plots were chosen randomly within 3 selected study areas: primary Dipterocarp forest; and two secondary Dipterocarp forests, including 8 months, and 6 years forest after selective logging with three replicates each. Vegetation analysis was carried out using $20 \times 20 \mathrm{~m}^{2}$ quadrat method, and 36 soil samples were taken and analyzed its soil nutrients, including total content of C-organic, total as well as available content of nitrogen, phosphorous, and potassium.

The results showed that 8 months secondary forest had dominated by pioneer plant of grass (Scleria sp.). Six-year secondary forest had dominated by pioneer trees such as Macaranga and climax species such as Shorea and Adenanthera. High abundance (20\% and $26 \%$ ) of climax vegetation saplings in 6-yearold secondary forest increased its similarity index close to primary forest. The high available phosphorus content in soil may induce the growth of both pioneer and climax plant species in the 6-year secondary forest compared to other forests. The different trend showed in the 8 month secondary forests that selective logging practices enriched soil nutrients contents except for available phosphorous.
\end{abstract}

Keywords : Selective logging; succession; lowland Dipterocarp forest; west Kutai

\section{INTRODUCTION}

Lowland Dipterocarp forest ecosystem in West Kutai is one of specific tropical rainforest ecosystem in Kalimantan island, Indonesia (Slik, et.al., 2003; Wullffraat, 2012) that cover area of 5,550,942 ha (Indonesian Ministry of Forestry, 2011). From this area, almost $20 \%$ of them had been managed as 24 timber concessions (under ministry of forestry's decree, IUPHHK-HA) for potential high economic log production that cover area of 1.489.231 ha (Sutisna, 2001; Wullffraat, 2012). As tropical rain forest natures, lowland Dipterocarp forests have clean forest floor, various niches, high diversity, fast decomposition rate, nutrients were saved in biomass not in forest soils (Ewusie, 1980; MacKinnon et. al., 1996; Whitmore, 1998). Therefore any disturbances, such as logging or landslides result stand or seedling damages, including changes in forest structure and forest composition (Hendrison, 1990; Cannon, et.al., 1994; Okuda et. al., 2003), and also soil nutrients were altered (Nussbaum, et.al., 1995).

Selective logging management had been practiced in West Kutai since more than 20 years instead of clear cut. This practice still deteriorated stand left (Cannon, et.al., 1994), resulted an open land area (Sutisna, 2001), and soil compaction (Williamson and Neilsen, 2000). This also changed vegetation structures and composition (Hendrison, 1990; Cannon,

ISSN 2413-0877 @ 2015 The Authors.

Published by KnowledgeE Publishing Services This is an open access article under the CC BY-NC-ND license (http://creativecommons.org/licenses/by-nc-nd/4.0)

Selection and Peer-review under responsibility of the 3rd ICBS-2013

Doi http://dx.doi.org/10.18502/kls.v2i1.147 
et.al., 1994; Okuda et. al., 2003) and indirectly altered forest floor microclimate condition (Whitmore, 1998; Saner, et. al., 2009). Natural secondary succession process have been going on in the lowland Dipterocarp forest after selective logging, with sere structures of plant community dynamics following time abandoning. Based on these conditions, therefore some question raised: a. What are the difference between forest structures of 8 months, 6 years, and dense (primary) forest? ; b. What are the dominant sere species of each time of succession? ; and c. How do soil nutrients change after 8 months and 6 years of natural succession? The purposes of this research were to study secondary succession in lowland Dipterocarp forest after 8 months and 6 years of Selective Logging in Long Pahangai, West Kutai regency.

\section{MATERIALS AND METHODS}

This study was carried out in concession forest area of PT Rodamas Timber in Long Pahangai, West Kutai Regency from May to November 2013 (Fig.1.). Three selected areas were chosen represented two secondary successions, including 8 months and 6 years after selective logging practices, and one area represented dense (primary) forest. Vegetation analysis was conducted in each area using six of $20 \times 20 \mathrm{~m}^{2}$ plots both for trees and saplings and four of $2 \times 4 \mathrm{~m}^{2}$ plots each for forest floor analysis. Environmental condition such as light, soil temperature, soil humidity, and soil pH were recorded, and 36 soil samples were collected for nutrient analysis of carbon, nitrogen, phosphorus and potassium contents.

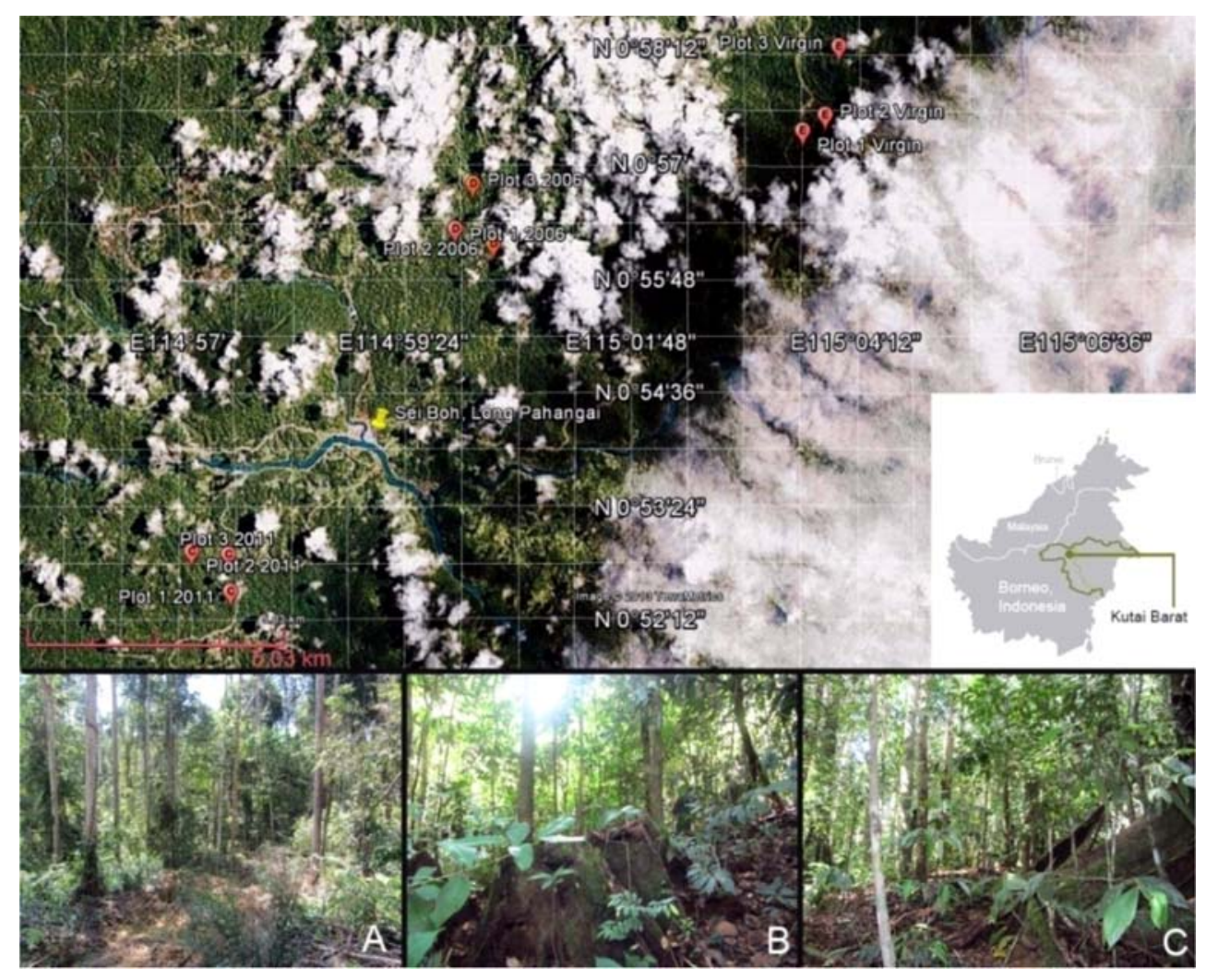

Figure 1. Study area in Long Pahangai, West Kutai, East Kalimantan. (A) secondary forest of 8 months after selective logging, and (B) secondary forest of 6 years after selective logging; (C) primary forest. 
Plots of primary forest was located on a hilly structures from $0^{\circ} 57^{\prime} 9.41^{\prime \prime} \mathrm{N} ; 115^{\circ} 3^{\prime}$ 36.54" E to $0^{\circ} 58^{\prime} 3.11^{\prime \prime} \mathrm{N}$; $115^{\circ} 3^{\prime}$ 59.66" E, with elevation of 427-450 m asl. (above sea level). The area was dense forest, with closely joined canopy and many bigger diameter trees found, and forest floor was dominated by litter. Average temperature in the forest was $22^{\circ}-26^{\circ} \mathrm{C}$

Plots in secondary forest of 6 years after selective logging was located on a hilly structures from $0^{\circ} 56^{\prime} 8.00^{\prime \prime} \mathrm{N}, 114^{\circ} 59^{\prime} 56.00^{\prime \prime} \mathrm{E}$ to $0^{\circ} 56^{\prime} 36.85^{\prime \prime} \mathrm{N}, 115^{\circ} 0^{\prime} 7.29 " \mathrm{E}$, with elevation of $283 \mathrm{~m}$ asl. at the slope of $20^{\circ}$.

Plots in secondary forest of 8 months after selective logging was located on a hilly structures from $0^{\circ} 52^{\prime} 17.18^{\prime \prime} \mathrm{N}, 114^{\circ} 57^{\prime} 32.97^{\prime \prime} \mathrm{E}$ to $0^{\circ} 52^{\prime} 41.00^{\prime \prime} \mathrm{N}, 114^{\circ} 57^{\prime} 32.00^{\prime \prime} \mathrm{E}$, with elevation of $292-330 \mathrm{~m}$ asl., slope $<20^{\circ}$. Average temperature in the forest was $27^{\circ}-31^{\circ} \mathrm{C}$.

\section{RESULTS AND DISCUSSIONS}

\section{Forest structure and vegetation composition of lowland Dipterocarp forest}

Forest structure of 8 months lowland secondary Dipterocarp has the shortest structure compared to 6 year and primary Dipterocarp forest, with average tree height less than $21 \mathrm{~m}$ and tree diameter less than $50 \mathrm{~cm}$, while in the 6 year secondary and primary Dipterocarp forest, trees with $30 \mathrm{~m}$ height with wider canopy and average tree diameter varies from 60 $70 \mathrm{~cm}$ were still found (Fig. 2).

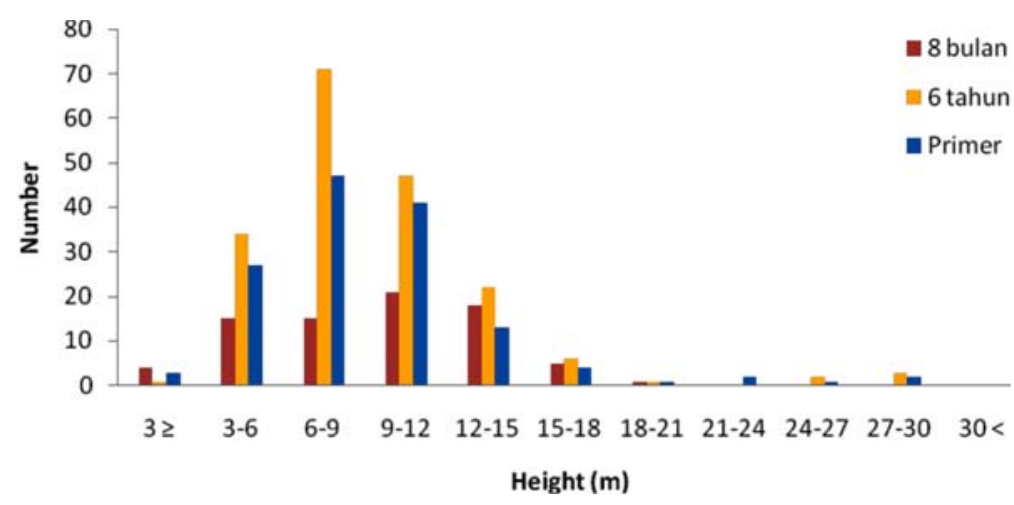

Figure 2. Tree height distribution of 8 months, 6 years secondary and primary lowland Dipterocarp forest in Long Pahangai, West Kutai, East Kalimantan

Three dominant family of tree stands found in 8 months secondary Dipterocarp forest in Long Pahangai were Dipterocarpaceae followed by Anacardiaceae and Dilleniaceae; while in saplings stand Dipterocarpaceae, Euphorbiaceae, and Hypericaceae were dominated forest composition (Fig. 3.a.). Selective logging practices in this case facilitated solar radiation to penetrate forest floor which was full of saplings from some dominant fast growing tree species before. According to Slik et al. (2003), Euphorbiaceae may have many life forms with varies of canopy height compared to Dipterocarpaceae.

Vegetation composition in the 6 year secondary Dipterocarp forest showed that more than sixty percent vegetation composition in 6 year secondary Dipterocarp forest was still sapling. The high sapling abundance is triggered by higher sun intensity that was still penetrating between an open canopy due to selective logging practices (Clark and Covey, 2012). The most dominant (more than 50\%) tree species in this station belonged to the family of 
Dipterocarpaceae (Shorea sp.) and Leguminosae (Adenanthera sp.); while for sapling, Macaranga spp. and Macaranga hypoleuca were the most dominant. Even the most dominant tree species (both Shorea sp and Adenanthera sp) were found with bigger trunk diameter, however, the whole area base width was still below $50 \%$ of the area base of the primary forest (Cannon et al., 1994). This therefore considered that the natural succession still need longer time to become climax as the primary forest.

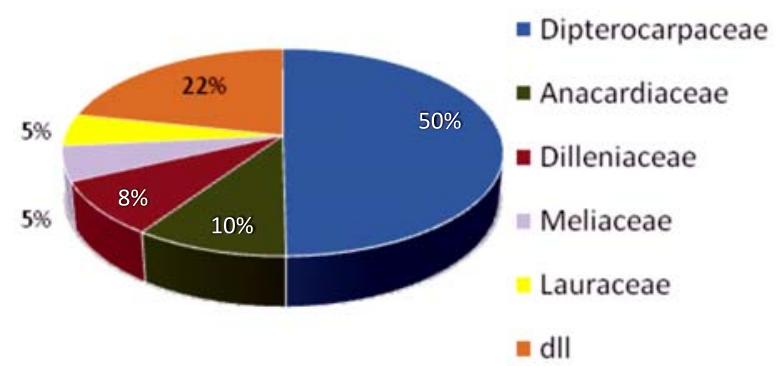

(a)

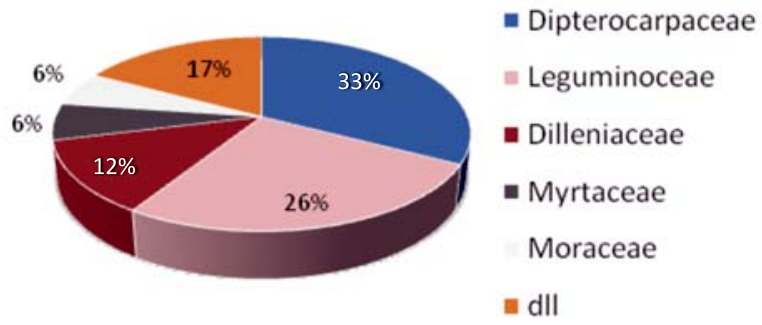

(b)

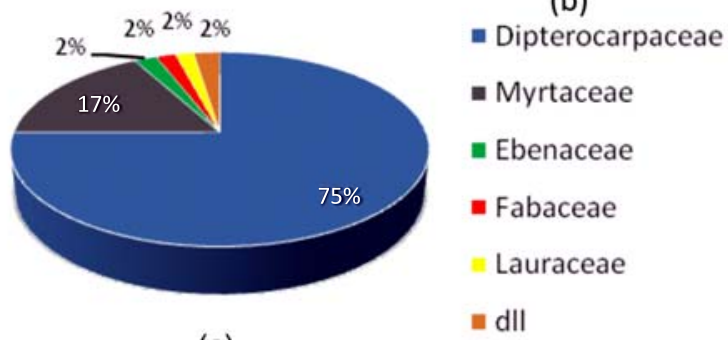

(c)

Figure 3. Tree and sapling dominancy in family groups (\%) based on area base width of lowland secondary Dipterocarp forest of (a) 8 months, (b) 6 years after selective logging practices, and (c) primary forest as comparison.

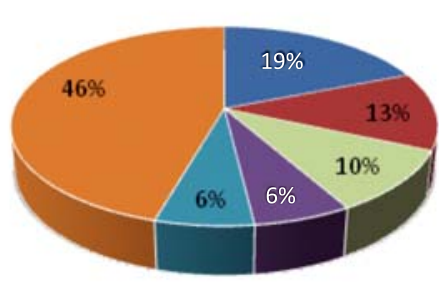

(a)

\section{- Dipterocarpaceae \\ - Dilleniaceae \\ = Euphorbiaceae \\ - Burseraceae \\ - Hypericaceae \\ $=\mathrm{dll}$}

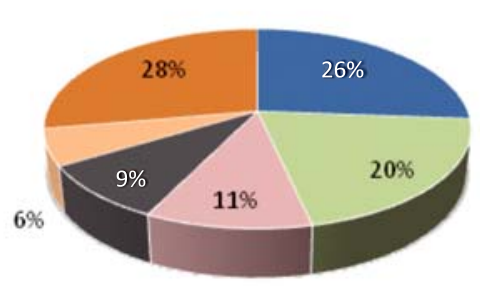

(b)
- Dipterocarpaceae

m Euphorbiaceae

= Leguminoceae

- Myrtaceae

= Sapotaceae

m dII

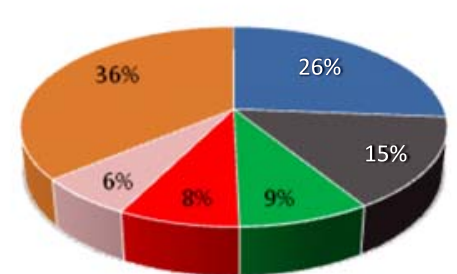

(c)
- Dipterocarpaceae

- Myrtaceae

- Ebenaceae

- Fabaceae

= Leguminoceae

and

Figure 4. Percentage of tree and sapling composition based on family groups in Lowland Secondary Dipterocarp forest of (a) 8 months, (b) 6 years after selective logging practices, and (c) primary forest as comparison 
Slightly similar trend of vegetation composition in secondary forest after 55 year of logging in the central Borneo was also reported by Brearley et al. (2004), that three most dominant families were Hypericaceae, Dipterocarpaceae dan Leguminoceae, while in the primary forest had been dominated more by Dipterocarpaceae dan Fabaceae. This seems that those families are the common sera stages towards advanced succession in lowland Dipterocarp forest.

\section{Diversity and similarity between three different conditions in lowland Dipterocarp forest in Long Pahangai, West Kutai}

Natural succession processes involving many sera species from pioneer to climax species, from sun tolerant to shading tolerant species (Barbour et al., 1987). Selective logging practices, as a disturbance for lowland Dipterocarp forest, trigger vegetation resilience that behaves differently between 8 months, 6 years after selective logging, and primary forest. Species richness among 3 different forests showed that 6 years after selective logging had the highest species richness, with the value of 93 species, and the highest diversity index with the value of 4.19 (Table 1). Both secondary forest of 8 months after selective logging and primary forest had similar species richness, but their diversity indices were far different. This happened because density of each composed species was not equal. Forest floor of the 8 months forest dominated by grasses of Scleria sp. (found 12,738 individual) which grew in a clumped distribution that may create so called "arrested succession" and this disturbs natural succession (Paul et al., 2004), therefore the diversity index was low.

Table 1. Diversity Indices (Shannon-Wiener) of Vegetation in 8 months, 6 year after selective logging of secondary lowland Dipterocarp and primary Dipterocarp forest in Long Pahangai, West Kutai, East Kalimantan

\begin{tabular}{llcc}
\hline No. & Dipterocarp forest & Species Richness & Diversity index \\
\hline 1. & 8 months after $\mathrm{SL}^{*}$ & 70 & 1.53 \\
2. & 6 years after $\mathrm{SL}^{*}$ & 93 & 4.19 \\
3. & Primary forest & 70 & 3.88 \\
\hline
\end{tabular}

The most interesting result found in the 6 years after selective logging forest is that, there was a promising change in seedling abundance, from pioneer species to climax species, Adenanthera, Syzigium, and Shorea, even though basal area of climax species were still low (Fig. 3 and 4.) This trend was also shown in the similarity indices of some growth form between 6 years after selective logging and primary Dipterocarp were high in trees, sapling and seedling with the figure of $48.8 \%, 35.9 \%$, and $27.5 \%$ respectively (Table 2.). Similar results were also found for climax species in the lowland Dipterocarp forest in 2003, which are Adenanthera, Shorea and Diospyros (Slik et al., 2003).

Slik et al. (2003), found that Macaranga is fast growing pioneer species that may regenerate from seed-banks which were abundant in the forest floor due better micro climatic condition (Raich and Khoon, 1990) after selective logging practices. The faster growing of Macaranga may reduce soil nutrients, such as total $\mathrm{C}$, available $\mathrm{N}$ and $\mathrm{P}$ (Aoyagi et al., 2013), even though it facilitated by the growth from the previous pioneer sera. These 
processes therefore will facilitate soil nutrients for the next succession sera, the shading tolerant species.

Table 2. Similarity indices (SOrensen) of Vegetation between 8 months, 6 year after selective logging of secondary lowland Dipterocarp and primary Dipterocarp forest in Long Pahangai, West Kutai, East Kalimantan

\begin{tabular}{clccc}
\hline No. & \multirow{2}{*}{ Growth-form } & \multicolumn{3}{c}{ Similarity indices (\%) } \\
\cline { 3 - 5 } & & 8 mos to 6 yrs & 8 mos to primary & 6 yrs to primary \\
\hline 1. & Trees & 5.9 & 4.6 & 48.8 \\
2. & Saplings & 12.2 & 6.1 & 35.9 \\
3. & Seedlings & 8.2 & 11.2 & 27.5 \\
4. & Lianas & 16.1 & 6.2 & 21.0 \\
5. & Shrubs & 0 & 0 & 28.6 \\
6. & Herbs & 1.7 & 4.2 & 0 \\
7. & Ferns & 22.6 & 0 & 17.2 \\
8. & Grasses & 0 & 0 & 0 \\
\hline
\end{tabular}

Of the soil nutrient content analysis, it clearly showed that soil fertility parameter of total Carbon, available Nitrogen, and exchangeable Potassium were higher compared to 2 other forests except for available Phosphorus (Table 3.). Selective logging practices abandoned some twigs, litter, and roots of trees in the field, and forest floor vegetation was mostly dominated by grasses. Degradation of this organic resource pool, especially complex carbon took longer time, and nutrient return obtained from dominant pioneer species (Scleria sp.) is high due to high turnover rate. The lower soil content of both available Potassium and Nitrogen (nitrate) in the 6 years secondary forest is because these nutrients are mobile nutrients that were susceptible to leaching (Maimer, 1996; Williams and Melack, 1997; Dezzeo and Chacon, 2006) process by erosive rainfall due to high average of rainfall in Kalimantan. Extremely high concentration of available soil Phosphorus in the 6 years forest, however, showed that this played key role for the fast vegetation resilience after selective logging, since phosphorus is a limited growth factor in tropical forest (Bazzaz, 1991; Brearley et al., 2007; Reed et al., 2011). Six years probably is the optimal duration for P degradation from tree roots of the selected log species.

Table 3. Soil fertility parameter in 8 months and 6 years after selective logging, and primary lowland Dipterocarp forest in Long Pahangai, West Kutai.

\begin{tabular}{lrrr}
\hline \multirow{2}{*}{ Soil fertility parameter } & \multicolumn{2}{c}{ Secondary forest } & Primary \\
\cline { 2 - 3 } & 8 Months & 6 Years & \multicolumn{1}{c}{ Forest } \\
\hline Total Carbon ( \% C ) & $\mathbf{7 . 6 3}$ & 3.34 & 3.83 \\
Available Nitrogen (N, ppm) & $\mathbf{4 7 8 . 2 3}$ & 342.32 & 399.33 \\
Available Phosphorus (P, ppm) & 0.17 & $\mathbf{0 . 6 5}$ & 0.18 \\
Exchangeable Potassium (K, me/100 g) & $\mathbf{0 . 3 7}$ & 0.22 & 0.36 \\
\hline
\end{tabular}

The 8 month secondary forest had dominated by pioneer plant of grass (Scleria sp.). Six-year secondary forest had dominated by pioneer trees Macaranga and climax species of Shorea and Adenanthera. High abundance (20\% and $26 \%$ ) of climax vegetation saplings in 6-year-old secondary forest increased its similarity index close to primary forest. The high available phosphorus content in soil may induce the growth of both pioneer and climax 
plant species in the 6-year secondary forest compared to other forests. The different trend showed in the 8 month secondary forests that selective logging practices enriched soil nutrients contents except for available phosphorous.

\section{REFERENCES}

Aoyagi, R., N. Imai and K. Kitayama. 2013. Ecological significance of the patches dominated by pioneer trees for the regeneration of dipterocarps in a Bornean logged-over secondary forest. Forest Ecology and Management 289: 378-384

Barbour, M.G., J.H. Burk, and W.D. Pitts. 1987. Terestrial Plant Ecology. The Benyamin/ Cummings Publishing Company Inc. California. P. 76, 164-165, 192-193, 198, 230243, 255, 260.

Bazzaz, F.A. 1991. Regeneration of Tropical Forests: Physiological Responses of Pioneer And Secondary Species. P. 91-111. In A. Gomes-Pampa, T.C. Whitmore and M. Hadley (eds.), Rainforest regeneration and management. Man and the Biosphere Series vol. 6. UNESCO, Paris, France.

Brearley, F.Q., J.D. Scholes, M.C. Press, and G. Palfner. 2007. How does light and phosphorus fertilisation affect the growth and ectomycorrhizal community of two contrasting dipterocarp species? Plant Ecol 192: 237-249

Cannon, C.H., D.R. Peart, M. Leighton, and K. Kartawinata. 1994. The Structure of Lowland Rainforest after Selective Logging in West Kalimantan Indonesia. Forest Ecology and Management 67: 49-68

Clark, J.A. and K.R. Covey. 2012. Tree species richness and the logging of natural forests: A meta-analysis. Forest Ecology and Management 276: 146-153

Dezzeo, N. and N. Chacon. 2006. Harat fluxes in incident rainfall, throughfall, and stemflow in adjacent primary and secondary forests of the Gran Sabana, southern Venezuela. Forest Ecology and Management 234: 218-226.

Ewusie, J.Y. 1980. Elements of Tropical Ecology. Anchor Brandon Ltd. London. P. 141-144. Hendrison, J. 1990. Damage-Controlled Logging in Managed Tropical Rain Forest in Suriname. Wageningen Agricultural University. P. 4, 7-10

Indonesian Ministry of Forestry. 2011. Data dan Informasi Pemanfaatan Hutan Tahun 2011. Direktorat Jenderal Planologi Kehutanan. Jakarta. Hal. 92-97

MacKinnon, K., G. Hatta, H. Halim, and A. Mangalik. 1996. The Ecology of Kalimantan. Periplus Edition. Singapore. p. 30-31, 165-166, 175-199, 403-407

Maimer, A. 1996. Hydrological effects and harat losses of forest plantation establishment on tropical rainforest land in Sabah, Malaysia. Journal of Hydrology 174: 129-148

Nussbaum R., J. Anderson, and T. Spencer. 1995. Factors limiting the growth of indigenous tree seedlings planted on degraded rainforest soils in Sabah, Malaysia. Forest Ecology and Management 74: 149-159

Okuda T., M. Suzuki, N. Adachi, E. S. Quah, N. A. Hussein, and N. Makoran. 2003. Effect of Selective Logging on Canopy and Stand Structure and Tree Species Composition in a Lowland Dipterocarp Forest in Penincular Malaysia. Forest Ecology and Management 175: $297-320$

Paul J. R., A. M. Randle, C. A. Chapman, and L. J. Chapman. 2004. Arrested succession in 
logging gaps: is tree seedling growth and survival limiting? African Journal of Ecology 42: $245-251$.

Reed, S. C., A. R. Townsend, P. G. Taylor, and C. C. Cleveland. 2011. Phosphorus Cycling in Tropical Forests Growing on Highly Weathered Soils. P. 339-369. In E.K. Bünemann, A. Oberson, and, E. Frossard. Phosphorus in Action: Biological Processes in Soil Phosphorus Cycling. Soil Biology vol. 26. Springer Berlin Heidelberg.

Saner, P., R. Lim, B. Burla, R. C. Ong, M. Scherer-Lorenzen, A. Hector. 2009. Reduced soil respiration in gaps in logged lowland dipterocarp forests. Forest Ecology and Management 258: 2007-2012

Slik, J. W. F., A. D. Poulsen, P. S. Ashton, C. H. Cannon, K. A. O. Eichhorn, K. Kartawinata, I. Lanniari, H. Nagamasu, M. Nakagawa, M. G. L. van Nieuwstadt, J. Payne, Purwaningsih, A. Saridan, K. Sidiyasa, R. W. Verburg, C. O. Webb, and P. Wilkie. 2003. A floristic 